\title{
Yellow Fever: Outbreak and Possible Causes Involved
}

\author{
Bárbara Letícia Figueiredo Fonseca ${ }^{1}$, Gabriela Castro Guimarães ${ }^{1}$, Renata Maciel da Silva ${ }^{1}$, Fabíola de \\ Almeida Brito*1,2 and Raphael de Souza Pinto*1,2 \\ ${ }^{1}$ Centro Universitário Cesmac (CESMAC), Brazil \\ ${ }^{2}$ Programs of Environmental Systems Analysis (PPGASA- CESMAC), Brazil
}

*Corresponding author: Fabíola de Almeida Brito, Programs of Environmental Systems Analysis (PPGASA- CESMAC), Centro Universitário Cesmac (CESMAC), Brazil

Raphael de Souza Pinto, Programs of Environmental Systems Analysis (PPGASA- CESMAC), Centro Universitário Cesmac (CESMAC), Brazil

\section{ARTICLE INFO \\ Received: 慧 February 02, 2019 \\ Published: 幽 February 21, 2019}

Citation: Bárbara Letícia Figueiredo F, Gabriela Castro G, Renata Maciel da S, Fabíola de Almeida B, Raphael de Souza P. Yellow Fever: Outbreak and Possible Causes Involved. Biomed J Sci \& Tech Res 14(5)-2019. BJSTR. MS.ID.002624.

\section{ABSTRACT}

Yellow fever (YF) is an acute infectious disease caused by an arbovirus, transmitted by mosquitoes of the genera Homologues, Sabetha's and Aedes. The YF has two mechanisms of transmission: urban and wild and has now gained relevance for outbreaks in large urban centers. Aedes aegypti is the main vector in both South America and Africa. Since December 2016, Brazil has been one of the largest outbreaks of wild-type yellow fever in its history, occurring in states in the Southeast region, mainly Minas Gerais and Espírito Santo, but also in Rio de Janeiro and São Paulo. Therefore, this study intends to quantify the cases of AF in Brazil between 2016 and 2018 and to relate these cases to the number of deaths, especially in the state of Minas Gerais, which is the target of recent environmental disasters. This is a descriptive epidemiological study, using data from the databases of the Brazilian Ministry of Health (Datasus), referring to the incidence of cases and deaths of yellow fever in humans, in the period of December 2016 to March 2017. Which refers to the summer season, which vors vector replication. It is concluded that studies on the environmental changes and adaptation of the contaminated vectors in the non-endemic regions should be carried out and new forms of prevention should be discussed.

\section{Introduction}

Yellow fever (YF) is an acute short-lived infectious disease, noncontagious, of varying severity. Aedes aegypti is the main vector in both South America and Africa. Since December 2016, Brazil has been one of the largest outbreaks of wild transmission in its history, with an important occurrence in states of the Southeast region, such as Minas Gerais, Espírito Santo, Rio de Janeiro and São Paulo [1]. YF epidemics are directly related to climate and social changes. Increased temperature and high humidity increase the voracity of the female mosquito by blood from monkeys and eventually humans to ensure the success of oviposition. Deforestation, natural disasters or the direct action of man, determine population displacements to areas close to forests, in addition to environmental imbalances, increase the possibility of contact with the mosquito [2].

Asymptomatic or mild forms are the majority of cases; about $20 \%$ develop into severe icteric forms and of these, the lethality is between 20 and 60\%. After the infected mosquito bites, the yellow fever virus spreads to dendritic cells, regional lymph nodes and the whole body [3]. The liver is one of the major affected organs, followed by the kidneys, spleen, heart and brain. In severe cases, hepatic necrosis due to coagulation is characterized by large destruction of hepatocytes, rapid diagnosis is very important $[2,3]$. In the past, yellow fever was one of the major problems for Brazilian public health but was controlled with the elimination of urban transmission in the country in 1942. However, with the impossibility of eradicating wild-type yellow fever, as it is a zoonosis of wild animals, and the wide dispersion of A. aegypti in Brazilian cities, the possibility of re-emergence of yellow fever in urban spaces is a threat constant. One of the largest outbreaks of AF was recorded in Brazil at the time of this study. All states in the Southeast region, except for São Paulo, were notified with a yellow fever epidemic in the period from December 2016 to 
March 2017. The affected municipalities are scattered in the state of Minas Gerais. Most of them are located near the state borders in the Rio Doce Basin. However, during the period of this study it was observed that the notifications in the databases of the Brazilian Ministry of Health, such as Datasus, only the state of Minas Gerais has its notifications disclosed, since it was the state with the highest number of cases of suspicion and confirmation of yellow fever in the study period [4].

\section{Materials and Methods}

This is a descriptive epidemiological study, using data from the databases of the Brazilian Ministry of Health (Datasus) and Scielo database and Capes periodicals, referring to the incidence of cases and deaths of YF in humans, in the period of December 2016 to March 2017. Which refers to the summer season, which vors vector replication.

\section{Results and Discussion}

During the period of research of this work we have seen that notifications in the databases of the Ministry of Health Brazilian, such as Datasus, only the state of Minas Gerais, have their notifications disclosed, since it was the state with the highest number of cases of suspicion and confirmation of yellow fever in the study period. Of the total confirmed cases of wild yellow fever, $405(86.7 \%)$ were male and $62(13.3 \%)$ were female. Among the deaths, 11 were female, representing $7.1 \%$ of all confirmed deaths. All cases were laboratory confirmed. The median age of confirmed cases is 48 years ( 0 - 88 years). The lethality of yellow fever in Minas Gerais in the period 2017/2018 is approximately $33.2 \%$, as shown in Table 1.

\section{ISSN: 2574-1241}

DOI: 10.26717/BJSTR.2019.14.002624

Fabíola de AB, Raphael de SP. Biomed J Sci \& Tech Res

CC (i) This work is licensed under Creative

Submission Link: https://biomedres.us/submit-manuscript.php
Table 1: Distribution of cases and confirmed deaths of Yellow

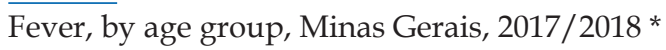

\begin{tabular}{|c|c|c|c|c|c|}
\hline Age Group & Cases & & Deaths & & Lethality \\
\hline years & $\mathbf{N}$ & $\mathbf{\%}$ & $\mathbf{N}$ & $\mathbf{\%}$ & $\mathbf{\%}$ \\
\hline 0 a 9 & 2 & 0,4 & 1 & 0,6 & 50 \\
\hline 10 a 19 & 14 & 3 & 1 & 0,6 & 7,1 \\
\hline 20 a 29 & 31 & 6,6 & 5 & 3,2 & 16,1 \\
\hline 30 a 39 & 67 & 14,3 & 14 & 9 & 20,9 \\
\hline 40 a 49 & 148 & 31,7 & 55 & 35,5 & 37,2 \\
\hline 50 a 59 & 91 & 19,5 & 33 & 21,3 & 36,3 \\
\hline 60 or more & 114 & 24,4 & 46 & 29,7 & 40,4 \\
\hline Total & 467 & 100 & 155 & 100 & 33,2 \\
\hline
\end{tabular}

Font: DVA/SVEAST/SES-MG - Date of update: 17/04/2018 * partial data, subject to change.

\section{Conclusion}

It is concluded that studies on the environmental changes and adaptation of the contaminated vectors in the non-endemic regions should be carried out and new forms of prevention should be discussed.

\section{References}

1. Cavalcante KRLJ, Tauil PL (2017) Risco de reintrodução da febre amarela urbana no Brasil. Epidemiol Serv Saúde 26 (3): 617-620.

2. Medeiros EAS (2018) Desafios para o controle e tratamento da febre amarela no Brasil. Acta Paul. Enferm 31(2).

3. Gotuzzo E, Yactayo S, Córdova E (2013) Efficacy and duration of immunity after yellow fever vaccination: systematic review on the need for a booster every 10 years. Am J Trop Med Hyg 89(3): 434-444.

4. (2018) Brasil Ministério da saude. Febre amarela: Ministério da Saúde atualiza casos no país.

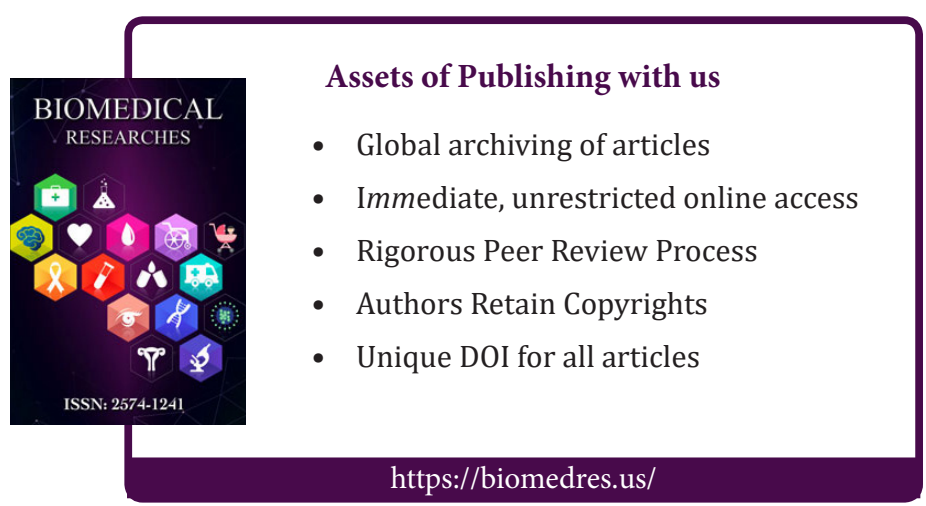

